Katrenko, M. V. (2011). Art pedagogy as a means of creative activity of students in physical education. dis. kand. ped nauk 13.00.04, Stavropol', 176. (in Russian)

Kuznecova, A. G. (2013). Formation of the basics of moral education of primary schoolchildren by means of art pedagogy in the sociocultural space of the organization of additional education. diss. kand. ped. nauk 13.00.02, Moskva, 177. (in Russian)

Rudenka, T. M. (2017). Form of professional competencies Maybach faculty of mystical specialties with art teacher training. dys. kand. ped. nauk 13.00.04. Zhytomyr, 237. (in Ukrainian)

Taranova, E. V. (2003). Moral education of senior preschoolers by means of art pedagogy. diss. kand. ped. nauk 13.00.01, Stavropol', 200 s. (in Russian)

Ty`menko V.P. (2011). Preparing maybutnikh designers with other major mortgages. Science Chronicle of the National Pedagogical University of Imeni M.P. Drahomanov. 26. 148-151. (in Russian)

Torchevska, N. V. (2019). The devotion of the artist to the plein air. Zb. sciences. etc. for materials V All-Ukrainian. science.-practical. conf. students, young students and science-ped. pracivnikiv «Architectural drawing in the context of professional education». Poltava: PoltNTU. 226-232. (in Ukrainian)

Umatova, A. U. (2014). Moral education of primary schoolchildren by means of art pedagogy. diss. kand. ped. n. 13.00.01, Mahachkala, 177 s. (in Russian)

Shumakova, N. Ju. (2006). Art pedagogy as a humanistic system of education of students in the field of physical education. dis. d. ped nauk 13.00.04, Stavropol', 402. (in Russian)

\title{
УДК: 374.7(-055.52)
}

DOI: https://doi.org/10.35387/od.2(16).2019.91-99

Котирло Тамара Володимирівна - старший науковий співробітник відділу андрагогіки Інституту педагогічної освіти і освіти дорослих імені Івана Зязюна НАПН України

ORCID ID: https://orcid.org/0000-0002-3256-5749

E-mail: kot_toma@ukr.net

\section{ПЕДАГОГІЗАЦІЯ БАТЬКІВ І ЧЛЕНІВ РОДИН ЯК АКТУАЛІТЕТ ОСВІТИ ДОРОСЛИХ}

Анотація. У статті проаналізовано актуальні дослідження у сорері освіти дорослих, в яких започатковано розв'язання проблеми педагогізації батьків і членів родин. Розкрито сутність понять «педагогізація» та «педагогічна культура». Охарактеризовано основні форми навчання батьків і залучення їх до виховної роботи. Здійснено аналіз проблеми педагогізації батьків, а саме: теоретикометодологічних підходів дослідження процесу формування їх педагогічної культури, тенденцій розвитку освіти досліджуваної категорії дорослих у системі нефрормальної освіти. Автором висвітлено пріоритети освіти $i$ просвіти батьків; особливості функціонування та організації 
педагогічної просвіти членів родин у системі неформальної освіти України; пріоритетні завдання освіти і просвіти батьків і членів родин в умовах сьогодення.

Акцентовано увагу на важливих аспектах роботи з батьками, таких як: популяризація діяльності психологічних служб для батьків $i$ членів родин; набуття психолого-педагогічних знань, які відповідають їхнім запитам щодо фрормування педагогічної культури; вибір оптимальних форм просвіти, що мотивують до набуття педагогічних $i$ психологічних знань, відповідних умінь і навичок; ознайомлення батьків із основами педагогічної майстерності для побудови суб'єкт-суб'єктних взаємин із дітьми.

Виокремлено та проаналізовано компоненти педагогічної культури батьків: мотиваційний, змістовий, конструктивний. Окреслено основні принципи взаємодії з батьками у процесі їх педагогізації, а саме: принцип професійної компетентності; принцип діагностичного підходу до родини; принцип спрямованості педагогічної освіти батьків на особистість дитини; принцип індивідуального підходу до родини. Доведено, що педагогізація сприяє удосконаленню педагогічних навичок $i$ здібностей батьків, актуалізує роздуми щодо необхідності створення сприятливих, оптимальних умов для виховання, розвитку й саморозвитку дітей.

Ключові слова: освіта дорослих, батьки, члени родин, неформальна освіта і просвіта батьків, педагогізація суспільства, педагогічна культура, усвідомлене батьківство.

Kotyrlo Tamara - Senior Researcher of the Department of Andragogy, Ivan Ziazun Institute of Pedagogical and Adult Education of the National Academy of Pedagogical Sciences of Ukraine

ORCID ID: https://orcid.org/0000-0002-3256-5749

E-mail:kot_toma@ukr.net

\title{
PEDAGOGIZATION OF PARENTS AND MEMBERS OF FAMILIES AS AN ACTUAL ISSUE OF ADULT EDUCATION
}

\begin{abstract}
The article analyzes current research in the field of adult education in which the problem of pedagogical education of parents and family members has been started. The essence of the concepts of "pedagogization» and "pedagogical culture» is revealed. The basic forms of education of parents and their involvement in educational work are characterized. The analysis of the problem of pedagogization of parents, namely theoretical and methodological approaches to the study of the process of formation of their pedagogical culture, tendencies of development of education of this of adults category and its importance in the system of non-formal education. The author highlights the essence of education of parents; peculiarities of functioning and organization of pedagogical education of family members in the non-formal education system of
\end{abstract}


Ukraine; priorities for education of parents and family members in the current environment.

There has been focused on important aspects of work with parents, such as: promoting the activities of psychological services for parents and family members; acquaintance with psychological and pedagogical knowledge, which corresponds to their queries regarding formation of pedagogical culture; selection of optimal forms of education that motivate the acquisition of pedagogical and psychological knowledge, relevant skills and competences; introducing parents to the basics of pedagogical skills for building subjectsubjective relationships with children.

The components of the pedagogical culture of the parents are distinguished and analyzed: motivational, content, constructive. The basic principles of interaction with parents in the process of their education are outlined, namely: the principle of professional competence; the principle of a diagnostic approach to the family; the principle of orientation of pedagogical education of parents on the child's personality; the principle of individual approach to the family. It is proved that pedagogization contributes to the improvement of pedagogical skills and abilities of parents, actualizes reflections on the need to create favorable, optimal conditions for the upbringing, development and self-development of children.

Key words: adult education, parents, family members, non-formal education and parental education, pedagogization of society, pedagogical culture, conscious parenting.

Постановка проблеми, її актуальність. Неформальна освіта дорослих $є$ актуалітетом сьогодення, своєрідним викликом для соціуму. Освіта дорослих - одна з важливих теоретичних і практичних проблем, про що свідчить значна кількість здійснених дослідницьких пошуків у цій сфері. Науковці розглядають феномен освіти дорослих як соціально-педагогічне, соціально-економічне та соціально-культурне явище.

Автори аналітичної записки «Освіта протягом життя як чинник людського розвитку», що була опублікована 14 травня 2015 року на сайті Національного інституту стратегічних досліджень, посилаючись на «Меморандум освіти протягом життя» (A Memorandum of Lifelong Learning), який був прийнятий на Лісабонському саміті Ради Європи у березні 2000 року, підкреслюють важливість безперервної освіти як головної політичної програми громадянського суспільства, соціальної єдності й зайнятості. Визначення безперервної освіти включає: отримання ступенів та дипломів у вільний час; профресійні курси, в тому числі з метою підвищення кваліфікації персоналу; освіта для дорослих; друга освіта інше. Також у Меморандумі було визначено шість принципів безперервної освіти: нові базові знання і навички для всіх, збільшення інвестицій в людські ресурси, інноваційні методики викладання й навчання, нова система оцінки здобутної освіти, розвиток наставництва й консультування, наближення освіти до місця проживання (Аналітична записка, 2015). 
Аналізуючи дані світової статистики в освітній сфері, бачимо, що загальна кількість дорослих, які навчаються, перевищує сумарну кількість дітей і молоді, які здобувають освіту у різних закладах освіти. Ця тенденція набуває все більших масштабів і на території сучасної України.

Однією зі складових освіти дорослих є педагогічна освіта і просвіта батьків, яка стала досить актуальною у наш час і потребує все більшої уваги суспільства, адже батьки, як перші наставники та педагоги, покликані створити умови для повноцінного становлення й розвитку особистості дитини. Говорячи про усвідомлене, відповідальне батьківство, передусім йдеться про намагання батьків «виліпити» з дитини досконалу особистість, витрачаючи на цей процес неабиякі зусилля. Водночас такі «добрі наміри» не завжди дають очікувані результати, що значною мірою залежить від багатьох фракторів: системи сімейних цінностей, рівня сформованості особистісної та педагогічної культури кожного з батьків, їх педагогічних здібностей тощо.

На нашу думку, розв'язання проблеми фрормування педагогічної культури батьків має стати основою взаємодії будь-якого суспільного інституту із сім'єю. Це питання має перебувати у полізору держави, адже труднощі у виконанні сім'єю виховної фрункції значною мірою пов'язані зі знеціненням моральних, духовних, громадянських ідеалів у суспільстві, відсутністю загальних стратегій виховання тощо.

Здійснений аналіз стану співпраці закладів дошкільної освіти і сім'ї засвідчує, що традиційні підходи до навчання й виховання дітей дошкільного віку малоефективні, незважаючи на те, що у багатьох нормативних документах нашої країни значна увага приділяється вирішенню проблем виховання підростаючого покоління. На жаль, у закладах дошкільної освіти ще недостатньо використовуються наукові досягнення щодо інтеграції зусиль педагогів і сім"ї задля виховання дітей (Новик, Ткаченко, 2017).

Акцентуємо увагу на тому, що нами було проведено локальне опитування серед батьків закладів дошкільної освіти, результати якого візуалізували освітні потреби батьків у сфрері педагогізації. Переважна більшість батьків (67\% респондентів) дали схвальні відповіді щодо доцільності та готовності набуття ними знань з педагогіки і психології, а також педагогічних умінь і навичок.

Аналіз останніх досліджень i публікацій. Проблеми нааціональної освіти дорослих викладено у працях О. Аніщенко, О. Василенко, О. Волярської, Л. Лук'янової, Н. Ничкало, С. Прийми, С. Сисоєвої, Н. Протасової та ін.

Значну увагу проблемі педагогічного просвітництва батьків, сімейного виховання та розвитку особистості дитини у сім'ї у наукових дослідженнях приділили А. Антонов, О. Безпалько, І. Братусь, А. Варга, 3. Зайцева, А. Захаров, С. Ковальов, Н. Кузнєцова, В. Леві, О. Лещенко,
А. Мудрик
Т. Поспілий,
А. Прихожан,
$€$ Є. Сичова,
А. Співаковська,

Т. Трапезніков, Н. Феоктистова та ін. 
Особливої уваги заслуговують праці Г.Лактіонової, в яких розкрито сутність усвідомленого батьківства як основи виховання дитини, зростання разом з нею, сприяння створенню найкращих можливостей для ії̈ стабільного та гармонійного розвитку.

Метою статті $€$ аналіз проблеми педагогізації батьків, обґрунтування особливостей педагогічного просвітництва та формування навичок компетентного батьківства. У дослідженні використано методи наукового спостереження, моделювання, узагальнення.

Виклад основного матеріалу дослідження. Для суспільства в цілому розвиток освіти дорослих сприяє суспільній єдності та взаємоповазі; розширенню соціально-політичного світогляду і, як наслідок, розширенню демократії; поширенню активного громадянства; посиленню культурної інтеграції (Ізбаш, 2018, с. 100). Соціальні та економічні зміни, які постійно відбуваються в Україні, вимагають від суспільства нових підходів до виховання дітей. Саме в дошкільному та шкільному віці дитина потребує уваги дорослих задля ії всебічного розвитку. Відповідальність батьків у цьому процесі $є$ найбільш вагомою.

Проведене нами опитування серед батьків і дорослих членів родин Закладу дошкільної освіти № 398 м. Києва щодо здатності сім'ї повноцінно виконувати свої виховні функції, за результатами відповідей респондентів (273 особи) ми одержали такі результати: повністю здатна 22\% (60 осіб); скоріше здатна, ніж не здатна - 41\% (112 осіб); скоріше не здатна, ніж здатна - 23\% (63 особи); повністю не здатна - 3\% (8 осіб); важко відповісти - 11\% (30 осіб). На жаль, відсоток батьків, які визнають, що не спроможні дати своїм дітям належне виховання у сім'ї, складає майже половину від кількості опитаних. Серед пояснень такої ситуації батьками названо брак часу, необізнаність на педагогічних питаннях, нерозуміння важливості родинного виховання, наявність матеріальних проблем у сім'ї тощо. Отримані дані свідчать про актульність здійснення педагогізації батьків і членів родин вихованців закладів дошкільної освіти та молодших школярів.

О. Нагула зазначає, що повноцінне сімейне виховання, основою якого $€$ компетентне відношення подружжя до батьківської ролі, істотно впливає на психічне здоров'я подальших поколінь. Психологічний клімат у родині, рівень психолого-педагогічної компетентності батьків впливають на емоційний стан та обумовлюють процес розвитку дитини на кожному віковому етапі. Особливо неповними є уявлення молодих сімей про функції батьків, організацію гармонічного виховання та розвитку дітей, а саме у розумінні змісту та значення батьківства, уявленнях про вагомість ролі батька та матері у виховному процесі, у їх оцінці власних можливостей у сімейному житті та майбутньому батьківстві (Нагула, 2012).

Взаємодія з родинами вихованців є одним із пріоритетних завдань діяльності закладів дошкільної та загальної середньої освіти. У законі України «Про освіту», «Про дошкільну освіту» одним із пріоритетних завдань задля забезпечення повноцінного розвитку дитини $є$ тісна 
взаємодія родини із закладом дошкільної освіти. 3 огляду на незначну кількість осередків неформальної освіти у сфері педагогізації батьків, саме ці заклади відіграють важливу роль у здійсненні педагогічного просвітництва серед дорослих членів родин шляхом поширення серед них психолого-педагогічних та інших знань. Отже, йдеться про педагогізацію досліджуваної категорії дорослих.

Слід зазначити, що вперше поняття педагогізація було сфрормульовано видатним педагогом С. Шацьким. «Педагогізація середовища» означала розробку теорії та методики взаємодії школи 3 іншими виховними закладами, вивчення й використання виховних можливостей соціального середовища в цілому; усвідомлене насичення, збагачення соціального середовища виховним потенціалом (Рижанова, 2010 , с. 267). У сучасних умовах педагогізація у закладах освіти відбувається завдяки консультативно-рекомендаційній та просвітницькій діяльності педагогічних працівників з батьками. Такі інтерактивні методи роботи, як групові семінари-практикуми, тренінги передбачають не лише теоретичне ознайомлення 3 проблемою, а й практичне розв'язання конкретних педагогічних задач, що постають перед батьками. Проведення спільних занять батьків і дітей емоційно зближують членів родин, розвивають інтерес один до одного, сприяють уважному ставленню та формуванню особистісних якостей усіх членів сім"ї.

У процесі нашого дослідження було розроблено модель педагогізації батьків (рис. 1). Відповідно до цієї моделі, педагогізація батьків і членів родин передбачає здобуття ними психологічних, педагогічних знань, а також набуття та удосконалення вмінь і навичок щодо діалогічної взаємодії з дітьми шляхом участі у традиційних та інтерактивних заходах, ініційованих закладами дошкільної і загальної середньої освіти, а також у процесі самоосвіти.

Сприяючи педагогізації родин та надаючи їм необхідну допомогу й підтримку у питаннях щодо виховання дітей, педагогічні працівники закладів дошкільної і загальної середньої освіти сприяють розвитку психолого-педагогічної культури батьків. В. Постовий зазначає, що дотримання цілісного підходу до вибору сукупності засобів, що забезпечують формування всіх компонентів педагогічної культури, а також урахування рівнів педагогічної підготовленості батьків і їх індивідуальних особливостей, досягнення наступності в поповненні знань і тісного їх взаємозв'язку з особистою практикою виховання дітей впливають на характер педагогічної культури батьків у процесі її формування (Постовий, 1994).

Педагогічну культуру сім'ї необхідно аналізувати як зміст взаємостосунків між батьками і дітьми через включення механізмів різних видів їх діяльності і втілення в цій діяльності моральних категорій (Шкелебей, 2016, с. 211). Педагогічна культура - не природжена якість. Вона розвивається, формується, піддається коригуванню, відточенню. Велику роль у цьому відіграють самоосвіта та самовиховання (Стельмах, 
2014, c. 259).

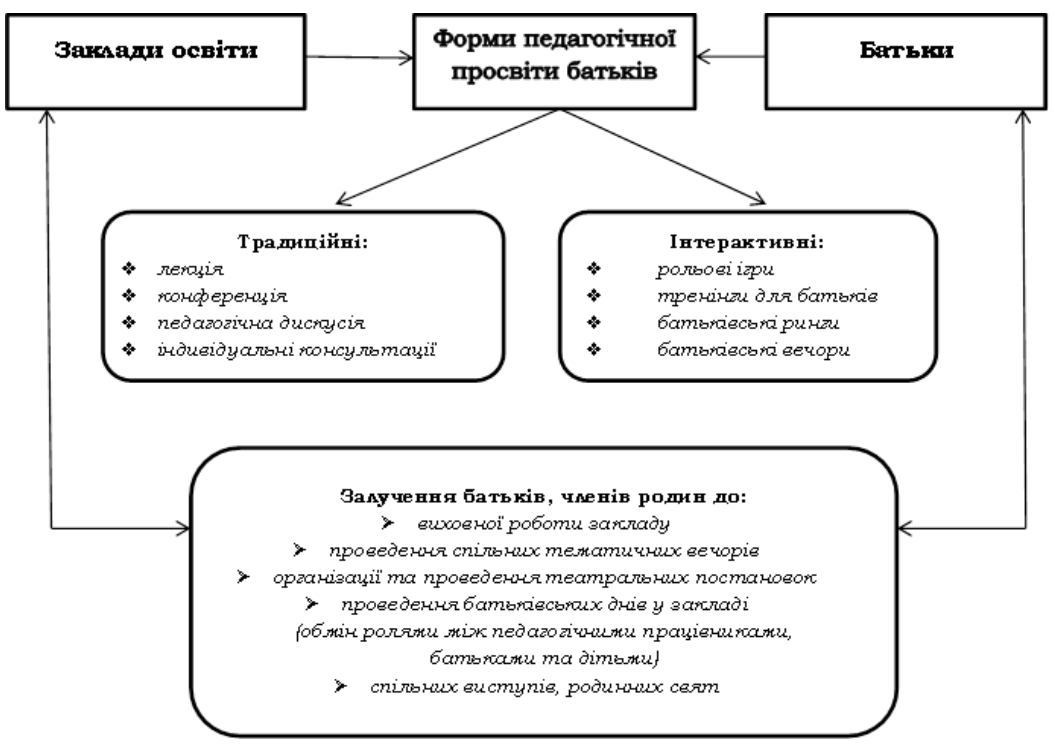

Рис. 1. Модель педагогізації батьків та членів родин

Досконалості у виробленні педагогічних умінь батьків можливо досягти лише за умови їх активної участі у вихованні та освіті власних дітей. Н. Стельмах акцентує увагу на шляхах розвитку та фрормування педагогічної культури вчителя, які також $є$ актуальними і для розвитку педагогічної культури батьків. Серед шляхів розвитку та фрормування педагогічної культури науковець виокремлює такі: оволодіння глибокими знаннями з педагогіки, психології, розширення педагогічної ерудиції; формування гуманістичної спрямованості у методах та засобах впливу на дітей, емоційно-позитивного забарвлення особистісного впливу на дітей тощо (Стельмах, 2014, с. 259).

Насамкінець зазначимо, що сім'я $€$ основою формування особистості дитини, джерелом емоційної підтримки. Аналізуючи сучасний стан педагогізації батьків можемо виокремити такі тенденції освіти і просвіти батьків і членів родин: зростання кількості психолого-педагогічних тренінгів, семінарів-практикумів щодо взаємодії з дітьми, що проводяться для батьків і членів родин; прагнення дорослих членів родин до самоосвіти та саморозвитку; збільшення кількості навчально-методичної літератури для батьків; поступове поширення ідей педагогізації батьків і членів родин та суспільства в цілому. Сучасна педагогіка, школа і сім'я відчувають потребу в науково обґрунтованих положеннях, рекомендаціях, що 
сприятимуть формуванню та вдосконаленню педагогічних компетентностей батьків і членів родин. Як свідчить аналіз наукових джерел (Цуркан, 2014, с. 37), суперечності соціального, педагогічного характеру, відсутність комплексних досліджень щодо вдосконалення педагогічного освіти і просвіти батьків, засвідчують актуальність порушеної проблеми, доцільність її грунтовного вивчення.

Висновки і перспективи подальших досліджень. Результати здійсненого дослідження дають підстави зробити висновок про те, що сучасним викликом суспільства є розвиток психолого-педагогічної культури батьків, що ґрунтується на міцних знаннях з питань загальної і соціальної педагогіки, психології, а також навичках, уміннях щодо діалогічної взаємодії 3 дітьми. Розроблення тренінгів для батьків і членів родин 3 метою підвищення їх психолого-педагогічної культури, створення мережі батьківських університетів задля освіти і просвіти батьків, членів родин, популяризація педагогізації дорослих через засоби масової інформації забезпечать правильність вибору батьками педагогічних впливів для взаємодії з власними дітьми. Компетентні батьки - це ті батьки, які вміють забезпечувати гармонійний розвиток дитини і діяти прогностично на основі аналізу наявних і можливих ситуацій, обставин щодо здійснення виховних впливів на дітей у родині. Усвідомлюючи силу власного прикладу, необхідність самовдосконалення, сучасні батьки готові до саморозвитку і самоосвіти у психолого-педагогічній сорері.

Перспективним напрямом подальших досліджень $є$ науковометодичне забезпечення освіти і просвіти батьків, членів родин у зарубіжній і національній педагогічній науці та практиці.

\section{Список використаних джерел}

Аналітична записка «Освіта протягом життя як чинник людського розвитку» URL: https://niss.gov.ua/doslidzhennya/gumanitarniyrozvitok/osvita-protyagom-zhittya-yak-chinnik-lyudskogo-rozvitku

Ізбаш, С. (2018). Андрагог як провідник процесу навчання дорослих. Наукові записки Бердянського державного педагогічного університету. Серія: Пед. науки: зб. наук. праць. Вип. 2. С. 100

Нагула, О.Л. (2012). Батьківська компетентність як чинник психічного розвитку дитини. Вісник Національної академії Державної прикордонної служби України. $5 . \quad$ URL: http://nbuv.gov.ua/UJRN/Vnadps_2012_5_44.)

Новик, І. М., Ткаченко, К. О. (2017). Педагогічне просвітництво батьків. Молодий вчений. 12 (52). 417-420

Постовий, В. Г. (1994). Сучасна сім'я та її педагогіка. К.: Освіта. 284 с.

Рижанова, А. О. (2010). С.Т. Шацький - засновник вітчизняної соціальної педагогіки. Вісник Харківської державної академії культури: зб. наук. праць. 31. 263-270.

Стельмах, Н.В. (2014). Педагогічна культура як фактор розвитку особистості. Науковий вісник Миколаївського національного 
університету імені науки. 1.47. 255-260.

Цуркан, Т.Г. (2014). Педагогічна освіта батьків. Педагогічний процес: теорія і практика. Частина I. Теорія педагогічного процесу. URL: http://nbuv.gov.ua/UJRN/pptp 2014 3 8. C.33-37

Шкелебей, В. (2016) Педагогічна культура батьків як один із важливих компонентів формування особистості молодшого школяра. Розвиток особистості молодшого школяра: сучасні реалії та перспективи: матеріали студентської науково-практичної інтернет-конференції. 211.

\section{References (translated and transliterated)}

Analytical note "Education for life as a factor of human development» URL: https://niss.gov.ua/doslidzhennya/gumanitarniy-rozvitok/osvita-protyagomzhittya-yak-chinnik-lyudskogo-rozvitku (14.07.2015). (in Ukrainian)

Izbash, S. (2018). Andragog as a leader in the adult learning process. Naukovi zapysky Berdyanskogo derzhavnogo pedagogichnogo universytetu. Seriya: Pedagogichni nauky: zb. nauk. pracz. 2. S. 100 (in Ukrainian)

Nagula, O. L. (2012). Parental competence as a factor in a child's mental development. Visnyk Nacionalnoyi akademiyi Derzhavnoyi prykordonnoyi sluzhby Ukrayiny. 5. URL: http://nbuv.gov.ua/UJRN/Vnadps_2012_5_44.) (in Ukrainian)

Novyk, I. M., Tkachenko, K. O. (2017). Pedagogical education of parents. Naukovy`j zhurnal «Molodyj vchenyj». 12 (52). 417-420 (in Ukrainian)

Postovyj, V. G. (1994). Modern family and its pedagogy. 284 s. (in Ukrainian)

Ryzhanova, A. O. (2010). S.T. Shatsky is the founder of national social pedagogy.. Visnyk Xarkivskoyi derzhavnoyi akademiyi kultury: zb. nauk. pracz. 31. 263-270. (in Ukrainian)

Stelmax, N. V. (2014). Pedagogical culture as a factor of personality development. Naukovyj visnyk Mykolayivskogo nacionalnogo universytetu imeni V. O. Suxomlynskogo. Seriya: Pedagogichni nauky. 1.47. 255-260. (in Ukrainian)

Czurkan, T. G. (2014). Pedagogical education of parents. Pedagogichnyj proces: teoriya i praktyka. Chastyna I. Teoriya pedagogichnogo procesu. 3. URL: http://nbuv.gov.ua/UJRN/pptp_2014_3_8. S.33-37 (in Ukrainian)

Shkelebej, V. (2016). Pedagogical culture of parents as one of the important components of formation of personality of the younger puple. Rozvytok osobystosti molodshogo shkolyara: suchasni realiyi ta perspektyvy: materialy studentskoyi naukovo-praktychnoyi internet-konferenciyi. 211 (in Ukrainian) 